\title{
Common bean elite lines cultivated under nitrogen fertilization and inoculation with Rhizobium tropici
}

\author{
Linhagens elite de feijoeiro-comum cultivadas com \\ fertilização nitrogenada e inoculação com Rhizhobium tropici
}

\author{
Helton Santos Pereira ${ }^{\mathrm{I}^{*}}$ Leonardo Cunha Melo ${ }^{\mathrm{I}}$ Luís Cláudio de Faria $^{\mathrm{I}}$ \\ Enderson Petrônio de Brito Ferreira ${ }^{\mathrm{I}}$ Fábio Martins Mercante \\ Adriane Wendland ${ }^{\mathrm{I}}$ Thiago Lívio Pessoa Oliveira de Souza ${ }^{\mathrm{I}}$
}

ABSTRACT

More efficient strains of Rhizobium have been selected for use in common bean. However, little effort was made with lines selection. The main goals of this research were to verify the presence of interaction involving common bean elite lines utilizing Nitrogen fertilization and Rhizobium inoculation for grain yield and to identify lines with superior yields utilizing biological nitrogen fixation. Eight field trials were conducted at four locationyears in Brazilian savanna, using randomized complete blocks design with three replications. Each trial was composed of 17 "carioca" elite lines. Every two tests in each location were planted side by side, one with mineral nitrogen fertilization (90kg) and the other one with inoculation with Rhizobium tropici SEMIA 4080 strain. Elite lines interaction with nitrogen fertilization/inoculation was not important, so, it is possible to select lines for utilization in both growing systems. In some locations-years, interaction between lines and Rhizobium inoculation was most affected by environment conditions, causing modification in lines classification according to the type of nitrogen supplying used. In general, the lines presented higher yields when fertilized with mineral nitrogen as compared with inoculation. The cultivar 'BRS Pontal' presented high and similar yields under both systems of nitrogen supply.

Key words: Phaseolus vulgaris, biological nitrogen fixation, grain yield, genotype by environment interaction.

RESUMO

Estirpes de rizóbio mais eficientes têm sido selecionadas para uso em feijoeiro-comum. Entretanto, pouco tem sido feito na seleção de linhagens mais eficientes. Os objetivos desse trabalho foram verificar a presença de interação entre linhagens elite de feijoeiro-comum com uso de fertilização nitrogenada $e$ inoculação com rizóbio, para produtividade de grãos e identificar linhagens com produção superior, quando inoculadas com rizóbio. Oito experimentos foram conduzidos em quatro locais/anos no cerrado brasileiro, compostos por 17 linhagens elite, em blocos ao acaso com três repetições. Em cada local/ano foram conduzidos dois experimentos, lado a lado: um com fertilização mineral de nitrogênio (90kg) e outro com inoculação com rizóbio. A interação entre as linhagens elite e o tipo de fornecimento de nitrogênio não foi importante, indicando que é possivel selecionar linhagens para uso simultâneo nos dois sistemas de cultivo. Em alguns locais, a interação entre as linhagens e a inoculação com rizóbio foi mais afetada pelo ambiente, causando modificações na classificação das linhagens nos dois tipos de fornecimento de nitrogênio. De modo geral, a produtividade foi maior utilizando-se fertilização mineral, quando comparada com a inoculação. A cultivar 'BRS Pontal' apresentou produtividade alta e semelhante nos dois sistemas de fornecimento de nitrogênio.

Palavras-chave: Phaseolus vulgaris, fixação biológica de nitrogênio, produtividade de grãos, interação genótipos $x$ ambientes.

\section{INTRODUCTION}

In the last few years, Brazil has been positioned as the greatest common bean (Phaseolus vulgaris L.) producer country (FAO, 2014) and its consumption represents an important source of protein to low income human populations. Approximately $65 \%$ of this grain production comes from small acreage properties, in which growth occurs in low fertility areas especially nitrogen deficient ones with employment of low levels of technology. The states of Goiás and the Federal District are included in Brazilian savanna, which is responsible for $39 \%$ of the total Brazilian common bean production, corresponding to one million metric tons (FEIJÃO, 2013).

\footnotetext{
'Embrapa Arroz e Feijão, Rodovia GO-462, km 12, 75375-000, Santo Antônio de Goiás, GO, Brasil. E-mail: helton.pereira@embrapa.br. ${ }^{*}$ Correspondig author.

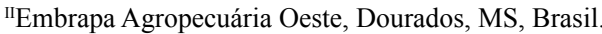


The utilization of nitrogen fertilizers leads to the achievement of higher grain yields, however the technology has been considered of low efficiency, since high amounts of the applied nitrogen is not absorbed by plants. In this context, the biological nitrogen fixation (BNF) assumes great importance, for it represents a viable alternative for nitrogen supply to the crop, due to low costs for the grower and both the prevention of contamination of water resources by the lixiviated nitrate and the reduction of emission of greenhouse effect gases (GRANGE et al., 2007; PELEGRIN et al., 2009).

Many studies with BNF have observed a low frequency of satisfactory response to inoculation of common beans under field conditions. This fact has been attributed to the susceptibility of both symbiotic organisms to several environmental factors such as high temperatures and low soil humidity, among others (HUNGRIA et al., 2000b; OLIVEIRA et al., 2011). To overcome these limitations, several studies have been conducted to identify strains of Rhizobia more efficient to BNF (CARDOSO et al., 2012). However, studies for the identification and selection of common bean lines more adapted to BNF are scarce (DEVI et al., 2013) and are almost always performed with lines with low agronomic potential. Identification of lines more responsive to BNF, particularly improved elite lines that present favorable traits accumulated in many years of selection, enable the direct use by farmers and also facilitate the incorporation of this trait via crossing.

Based on the information pointed out, the objectives of the present research were to verify the presence of the interaction for grain yield of "carioca" seeded common bean elite lines with the utilization of nitrogen fertilization and Rhizobium inoculation; and to identify "carioca" elite lines with high grain yields when inoculated with highly symbiotic efficient and competitive Rhizobium strains.

\section{MATERIALS AND METHODS}

Seventeen "carioca" type common bean elite lines, derived from eight different crosses, were utilized in this study as follows: four released cultivars ('BRS Pontal', 'Pérola', 'IPR Juriti', and 'BRS Cometa') and 13 elite lines. The field trials were conducted in the years of 2007 and 2008, in four combinations of years $x$ locations in Brazilian savanna (state of Goiás/Brazil), in the winter growing season (May/Jun.). The experimental design utilized was the complete randomized-block with three replications and plots comprised of four $4 \mathrm{~m}$ long rows.
The location by year combinations were as follows: Santo Antônio de Goiás, winter of 2007; Porangatu, winter of 2007; Santo Antônio de Goiás, winter of 2008; and Senador Canedo, winter of 2008. Winter sowing period in these locations is characterized by little precipitation, so the water was supplied by irrigation. Within each location by year combinations two field trials were assembled side by side, with the recommended $\mathrm{P}_{2} \mathrm{O}_{5}$ e $\mathrm{K}_{2} \mathrm{O}$ fertilization for the crop, but in one of the trials it was applied also Nitrogen fertilization at sowing time $\left(20 \mathrm{~kg} \mathrm{ha}^{-1}\right.$ of $\left.\mathrm{N}\right)$ and in side-dress with Urea, adding up $90 \mathrm{~kg} \mathrm{ha}^{-1}$ of N. In the other experiment, without $\mathrm{N}$ fertilization, seeds were inoculated with the $\boldsymbol{R}$. tropici strain SEMIA 4080 (PRF81) (HUNGRIA et al., 2000a), with density of $10^{9}$ cells $\mathrm{g}^{-1}$ of turf in the proportion of $500 \mathrm{~g}$ of inoculum per $50 \mathrm{~kg}$ of seeds. Yield data $\left(\mathrm{kg} \mathrm{ha}^{-1}\right)$ were collected in the two central rows.

Yield data were submitted to the analysis of variance considering treatment effect as fixed. Since the coefficient of variation is dependent of the means of the trials, selective accuracy was estimated (RESENDE \& DUARTE, 2007) for measuring experimental precision, through the expressions:

$\mathrm{SA}=\left(1-\frac{1}{F_{c}}\right)^{0,5}$, for $\mathrm{F}_{\mathrm{c}} \geq 1$; and $\mathrm{SA}=0$, for $\mathrm{F}_{\mathrm{c}}<1$, in which $F_{c}$ is the $F$ test value for cultivar.

From the yield means obtained in each experiment, for each environment it was established a ratio between grain yield with inoculation (without $\mathrm{N}$ fertilization) and grain yield with $\mathrm{N}$ fertilization (RYIF), as percentage, by the expression:

$\mathrm{RYIF}_{\mathrm{i}}=\left(\frac{X I_{i}}{X N_{i}}\right) * 100$ , in which: $\mathrm{XI}_{\mathrm{i}}$ is the mean yield of line $\mathrm{i}$ with inoculation; $\mathrm{XN}_{\mathrm{i}}$ is the mean yield of the line $\mathrm{i}$ with $\mathrm{N}$ fertilization.

It was also estimated Spearman correlations between grain yield averages with inoculation and with $\mathrm{N}$ fertilization at each environment. It was then performed the analyses of combined variance of all field trials over the four locations/years with decomposition of the line by environment interactions into line by $\mathrm{N}$ source $(\mathrm{N}$ fertilization vs. biologic $\mathrm{N}$ fixation) and line by location-year. In this analysis, lines, locations-years and $\mathrm{N}$ sources effects were considered fixed. The means of the treatments were compared according to Scott Knott and Tukey methods, at $10 \%$ probability level. It was also calculated the ratio between yields obtained with inoculation (without $\mathrm{N}$ fertilization) and those resulting from $\mathrm{N}$ fertilization (RYIF) (as percentages), 
based on the averages obtained in the combined analysis. The software GENES and SISVAR were used for performing the statistical analyses.

\section{RESULTS AND DISCUSSION}

$\mathrm{CV}$ (coefficient of variation) values for grain yield varied from 10 to $22 \%$, in different environments, demonstrating a satisfactory experimental precision, which was also confirmed by the high and very high estimatives of selective accuracy found for six experiments, and moderate for two experiments (CARGNELUTTI FILHO \& STORCK, 2009). The averages of grain yield obtained in each environment, varied from 840 to $2,920 \mathrm{~kg} \mathrm{ha}^{-1}$, indicating a wide environmental variation. Such variation may be confirmed by observing the geographic data of the locations of the field trials. Altitudes varied from 396 to 823 metros with latitudes ranging from $13^{\circ} 26^{\prime} \mathrm{S}$ to $16^{\circ} 42^{\prime} \mathrm{S}$. Yields obtained through the Rhizobium inoculation in different environments ranged from 840 to $2,535 \mathrm{~kg}$ $\mathrm{ha}^{-1}$, while with $\mathrm{N}$ fertilization yields obtained ranged from 1,176 to $2,920 \mathrm{~kg} \mathrm{ha}^{-1}$.

Ratio between the highest and the smallest error mean square was bellow seven, indicating that residual variances were homogeneous (PIMENTELGOMES, 2000). Combined analysis detected significant differences for the three main sources of variation, including lines (Table 1), which indicates

Table 1 - Summary of the combined statistical analysis, with decomposition of the line by environment interaction, for grain yield $\left(\mathrm{kg} \mathrm{ha}^{-1}\right)$ in eight "carioca" type common bean field trials conducted at the locations Santo Antônio de Goiás, Porangatu and Senador Canedo, in Brazilian savanna, during the winter growing season of 2007 and 2008.

\begin{tabular}{llll}
\hline Source of Variation & $\mathrm{DF}^{1}$ & \multicolumn{1}{c}{$\mathrm{MS}^{2}$} & P-value \\
\hline Block/Environment & 16 & 194,717 & 0.0001 \\
Lines (G) & 16 & 510,663 & 0.0000 \\
Location-Year (LA) & 3 & $57,140,114$ & 0.0000 \\
N Source (N) & 1 & $6,750,883$ & 0.0000 \\
G x LA & 48 & 323,362 & 0.0000 \\
G x N & 16 & 63,921 & 0.4577 \\
LA x N & 3 & $1,579,505$ & 0.0000 \\
G x LA x N & 48 & 106,176 & 0.0070 \\
Residual & 256 & 63,952 & - \\
Total & 407 & & \\
Mean & 1656 & & \\
CV $(\%)$ & 15.26 & & \\
\hline
\end{tabular}

${ }^{1} \mathrm{DF}$ : Degrees of freedom; ${ }^{2} \mathrm{MS}$ : Mean Squares. that there is real variability among the tested lines. Such variability can be explained because the 17 lines originated from eight different crosses. Other studies have also reported the existence of differences in grain yields among common bean lines under Rhizobium inoculation (BRITO et al., 2008).

The significance for $\mathrm{N}$ sources indicates that yields with $\mathrm{N}$ fertilization and with inoculation differed and that is confirmed by the yield means obtained through $\mathrm{N}$ fertilization $\left(1,785 \mathrm{~kg} \mathrm{ha}^{-1}\right)$ and under inoculation with Rhizobium $\left(1,527 \mathrm{~kg} \mathrm{ha}^{-1}\right)$ (Table 1). BRITO et al. (2008) found similar results upon evaluating elite lines of the black seeded commercial group. On the other hand, BRITO et al. (2010) found no differences between grain yields under $\mathrm{N}$ fertilization (60kg ha $\left.{ }^{-1}\right)$ and Rhizobium inoculation when evaluating different elite "carioca" type lines at the state of Mato Grosso do Sul/Brazil. PELEGRIN et al. (2009), working in the same state did not find differences between yields of the cultivar 'Pérola' under $\mathrm{N}$ fertilization (40 and $80 \mathrm{~kg}$ ha $^{-1}$ ) versus Rhizobium inoculation. Others papers related similar grain yield under $\mathrm{N}$ fertilization and Rhizobium inoculation (GRANGE et al., 2007).

The interaction between $\mathrm{N}$ sources and locations-years was significant, indicating the occurrence of differential response regarding to the use of $\mathrm{N}$ fertilization and the Rhizobium inoculation, depending upon locations-years. Results confirm the finding that the response to BNF in common beans is dependable upon environmental conditions and lines as well as upon the Rhizobium strains (OLIVEIRA et al., 2011; CARDOSO et al., 2012).

Interaction lines by locations-years was also significant (Table 1), indicating the existence of differential response of lines upon locations-years, which is frequently reported for the common bean crop (FARIA et al., 2013), including for the Brazilian savanna considering evaluations in the same growing season (PEREIRA et al., 2011; TORGA et al., 2013). Differently, the line by $\mathrm{N}$ sources was not significant, meaning that the performance of the lines was coincident in both $\mathrm{N}$ conditions, i.e. the most productive lines were the same regardless when the $\mathrm{N}$ was applied as fertilizer or supplied through Rhizobium inoculation.

The grain yield averages of the lines for each one of the $\mathrm{N}$ supplying sources demonstrate that those with better performance are the same (Table 2). The five best lines as far as the overall mean (CNFC 10762, 'BRS Pontal', CNFC 10763, 'IPR Juriti', and CNFC 10721) were the same ones with the highest yields under $\mathrm{N}$ fertilization and Rhizobium inoculation. 
Table 2 - Average yield grains $\left(\mathrm{kg} \mathrm{ha}^{-1}\right)$ with Rhizobium inoculation and with Nitrogen fertilization, and ratio between yield with inoculation and with N fertilization (RYIF) of 17 "carioca" type common beans lines evaluated in eight field trials conducted in Brazilian savannah, during the winter growing season of 2007 and 2008.

\begin{tabular}{|c|c|c|c|c|c|c|c|c|c|}
\hline \multirow{2}{*}{$\begin{array}{l}\text { Lines } \\
\text { CNFC } 10762\end{array}$} & \multicolumn{2}{|c|}{-----------Mean----------- } & \multicolumn{2}{|c|}{--------Nitrogenated------ } & \multirow{2}{*}{$\frac{\mathrm{C}}{1}$} & \multicolumn{2}{|c|}{---------Inoculated-------- } & \multirow{2}{*}{$\frac{\mathrm{C}}{4}$} & \multirow{2}{*}{$\begin{array}{r}\text { RYIF } \\
79.9\end{array}$} \\
\hline & 1867 & $\mathrm{a}$ & 2076 & $\mathrm{Aa}$ & & 1658 & $\mathrm{Ba}$ & & \\
\hline 'BRS Pontal' & 1841 & $\mathrm{a}$ & 1901 & $\mathrm{Aa}$ & 5 & 1781 & $\mathrm{Aa}$ & 1 & 93.7 \\
\hline CNFC 10763 & 1821 & $\mathrm{a}$ & 1981 & $\mathrm{Aa}$ & 3 & 1660 & $\mathrm{Ba}$ & 3 & 83.8 \\
\hline 'IPR Juriti' & 1815 & $\mathrm{a}$ & 1934 & $\mathrm{Aa}$ & 4 & 1696 & $\mathrm{Ba}$ & 2 & 87.7 \\
\hline CNFC 10721 & 1808 & $\mathrm{a}$ & 2005 & $\mathrm{Aa}$ & 2 & 1610 & $\mathrm{Ba}$ & 5 & 80.3 \\
\hline 'Pérola' & 1722 & $\mathrm{~b}$ & 1877 & $\mathrm{Aa}$ & 7 & 1566 & $\mathrm{Ba}$ & 7 & 83.4 \\
\hline CNFC 10742 & 1687 & $\mathrm{~b}$ & 1878 & $\mathrm{Aa}$ & 6 & 1497 & $\mathrm{Bb}$ & 11 & 79.7 \\
\hline CNFC 10733 & 1663 & $\mathrm{~b}$ & 1824 & $\mathrm{Ab}$ & 8 & 1501 & $\mathrm{Bb}$ & 9 & 82.3 \\
\hline CNFC 10758 & 1660 & $\mathrm{~b}$ & 1758 & $\mathrm{Ab}$ & 11 & 1561 & $\mathrm{Ba}$ & 8 & 88.8 \\
\hline CNFC 10729 & 1659 & $\mathrm{~b}$ & 1750 & $\mathrm{Ab}$ & 12 & 1568 & $\mathrm{Ba}$ & 6 & 89.6 \\
\hline CNFC 10716 & 1622 & $\mathrm{c}$ & 1759 & $\mathrm{Ab}$ & 10 & 1486 & $\mathrm{Bb}$ & 12 & 84.5 \\
\hline CNFC 10703 & 1594 & $\mathrm{c}$ & 1786 & $\mathrm{Ab}$ & 9 & 1402 & $\mathrm{Bb}$ & 15 & 78.5 \\
\hline CNFC 10753 & 1579 & $\mathrm{c}$ & 1658 & Ac & 13 & 1499 & $\mathrm{Ab}$ & 10 & 90.5 \\
\hline CNFC 10813 & 1503 & $\mathrm{~d}$ & 1594 & Ac & 14 & 1412 & $\mathrm{Bb}$ & 14 & 88.6 \\
\hline CNFC 10757 & 1484 & $\mathrm{~d}$ & 1526 & Ac & 15 & 1442 & $\mathrm{Ab}$ & 13 & 94.5 \\
\hline CNFC 10713 & 1469 & $\mathrm{~d}$ & 1590 & Ac & 16 & 1338 & $\mathrm{Bb}$ & 16 & 84.1 \\
\hline 'BRS Cometa' & 1371 & $\mathrm{~d}$ & 1452 & Ac & 17 & 1288 & $\mathrm{Bb}$ & 17 & 88.7 \\
\hline Mean & 1656 & - & 1785 & A & - & 1527 & B & - & 85.6 \\
\hline
\end{tabular}

Means followed by same letters within columns (Scott-Knott, $\alpha=0.10)$ and capital letters within lines (Tukey, $\alpha=0.10)$ do not differ statistically.

Hence the highest-average lines were grouped among the most productive in both conditions, demonstrating that the difference between the $\mathrm{N}$ sources did not affect the selection of the best lines.

Although this is a general trend, it may be observed the response to the two $\mathrm{N}$ sources was variable for some of the lines (Table 2). The line CNFC 10742, the sixth most productive under $\mathrm{N}$ fertilization (first group of averages according to the clustering test), was the $11^{\text {th }}$ upon Rhizobium inoculation (second group of averages). Furthermore, some lines presented the opposite performance such as CNFC 10729, ranked $12^{\text {th }}$ with $\mathrm{N}$ fertilization (second group of averages) and sixth with inoculation (first grouping). BRITO et al. (2010) observed a similar result as the one reported in the present research. Lines CNFC 10742 and CNFC 10729, which presented differentiated performance for each $\mathrm{N}$ source, as well as CNFC 10721, which showed good performance in both situations (Table 2), are originated of a multiple cross among six parents, demonstrating the great variability generated in this cross, favored by the use of several parental lines (CARNEIRO et al., 2002).

Upon comparison of overall line means for the two conditions of $\mathrm{N}$ supplying sources, the Spearman correlation (0.80) confirmed that the ranking of lines was not altered. Correlations between yield averages of the lines in the two $\mathrm{N}$ supplying conditions in three of the locations-years under environments under evaluation (Santo Antônio de Goiás-2007 and 2008, and Senador Canedo-2008), confirmed the consistence of the line ranking under the two conditions $(0.67$, 0.60 and 0.57 , respectively). Only at the location-year Porangatu-2007 the correlation was close to zero (0.04), indicating probably that the environmental conditions were much discrepant and so, they may have affected differently the performance of the lines.

Comparing the ratio between yield with inoculation versus with $\mathrm{N}$ fertilization (RYIF), 'BRS Pontal' outstood among the most productive lines presenting RYIF of $94 \%$ (Table 2), which indicates that this line could be utilized under both conditions with similar grain yield results. In addition to this line, CNFC 10753, CNFC 10757 and 'BRS Cometa' obtained analogous yields under both N-supply sources, although presenting averages inferior to the best lines. The majority of the lines obtained greater yields when fertilized with mineral $\mathrm{N}$, an indicative that probably the source of $\mathrm{N}$ utilized during the selection process directly affects the productive thresholds for common bean lines of the "carioca" type group. The results obtained considering the averages of the two types of $\mathrm{N}$ sources were confirmed by the means in the location-years considered separately. The average

Ciência Rural, v.45, n.12, dez, 2015. 
yield at three location-years (Santo Antônio de Goiás-2007 and 2008, and Porangatu-2007) under N fertilization was greater than that obtained through Rhizobium inoculation.

In general it may be observed that exists difference between grain yield upon utilization of $\mathrm{N}$ fertilization and inoculation with Rhizobium and that the interaction of "carioca" seeded elite lines with the source of $\mathrm{N}$ supply is not important in Brazilian savanna. Hence, among the available lines presently, the same lines would be selected for both types of nitrogen supply in Brazilian savanna. Selection of such lines, with wide adaptation to both conditions is important since it makes possible their utilization in each of the situations by the growers without imparting them any economic losses.

All lines utilized in this study were developed using $\mathrm{N}$ fertilization during the selective process (segregating population management and pure line selection) and therefore it is expected that natural selection would act as an aid to obtain higher yielding lines in such conditions (CORTE et al., 2002; SILVA et al., 2004). This was confirmed in the present research since there were differences in productivity between the two conditions of $\mathrm{N}$ supply (Table 1), with a higher productivity obtained through mineral $\mathrm{N}$ fertilization. Even so, some of the lines that presented good adaptation to the $\mathrm{N}$ fertilization were also responsive to the process of BNF, such as 'BRS Pontal'. This indicates that, even without selection for a specific trait during the process of pure line development, it is still possible to identify variability for this trait and lines with desirable phenotypes.

Hence it is possible to select elite lines for their insertion in breeding programs as sources of target traits even when they were not developed on favorable conditions for the expression of the trait. The utilization of elite lines that possess desirable agronomic traits and also favorable alleles for a target character may represent a great gain in efficiency in breeding programs to BNF, reducing the time for development of new cultivars.

Another ascertainment is that it was not found any line that presented higher yields upon BNF than those lines obtained with $\mathrm{N}$ fertilization. This attest that selection of lines for higher yield increments for the crop under BNF should be employed, preferentially, using this $\mathrm{N}$ source in the process of lines development, in order to obtain more favorable conditions to the expression of this trait.

\section{CONCLUSION}

The interaction of elite lines with nitrogen fertilization/inoculation was not important, so, it is possible to select lines for utilization in both growing systems. In some locations-years, interaction between lines and Rhizobium inoculation is most affected by environment conditions, causing modification in lines classification according to the type of nitrogen supplying used. In general, the lines presented higher yields when fertilized with mineral nitrogen as compared with inoculation. The cultivar 'BRS Pontal' presented high and similar yields under both systems of nitrogen supply.

\section{ACKNOWLEDGEMENTS}

To Emater Goiás, Brazil, for the support for the implementation and conduction of the field trials; to Embrapa Cerrados, for the provision of the inoculators; and to Conselho Nacional de Desenvolvimento Científico e Tecnológico (CNPq) for awarding a fellowship in technology development and innovatory extension to the fifth and second authors and a research fellowship to the seventh author.

\section{REFERENCES}

BRITO, O.R. et al. Evaluation of the Carioca and black beans group lines inoculated with Rhizobium tropici strains. Annual Report of Bean Improvement Cooperative, v.51, n.1, p.254-255, 2008. Available from: $<$ http://naldc.nal.usda.gov/naldc/download.xhtml?i $\mathrm{d}=$ IND44063322\&content=PDF $>$. Accessed: Jul. 28, 2014.

BRITO, O.R. et al. Nitrogen fertilization and inoculation with Rhizobium tropici in black bean. Annual Report of Bean Improvement Cooperative, v.53, n.1, p.172-173, 2010. Available from: <http://ainfo.cnptia.embrapa.br/digital/bitstream/item/51003/1/ BIC-2010-Annual-Report-172.pdf>. Accessed: Jul. 28, 2014.

CARDOSO J.D. et al., Polyphasic approach for the characterization of rhizobial symbionts effective in fixing N2 with common bean (Phaseolus vulgaris L.). Applied Microbiology Biotechnology, v.93, p.2035-2049, 2012. Available from: <http://www.alice. cnptia.embrapa.br/bitstream/doc/254697/1/01.pdf $>$. Accessed: Jul. 28, 2014. doi: 10.1016/j.soilbio.2007.01.001.

CARGNELUTTI FILHO, A.; STORCK, L. Medidas do grau de precisão experimental em ensaios de competição de cultivares de milho. Pesquisa Agropecuária Brasileira, v.44, p.111-117, 2009. Available from: <http://www.scielo.br/pdf/pab/v44n2/ v44n02a01.pdf>. Accessed: Jul. 28, 2014. doi: 10.1590/S0100204X2009000200001.

CARNEIRO, J.E.S. et al. Breeding potencial of single, double and multiple crosses in common bean. Crop Breeding and Applied Biotechnology, v.2, p.493-661, 2002. Available from: <http:// www.sbmp.org.br/cbab/siscbab/uploads/c8128f42-55c4-87db.pdf > Accessed: Jul. 28, 2014. doi: 10.12702/1984-7033.v02n04a04.

CORTE, H.R. et al. Natural selection for grain yield in dry bean populations bred by the bulk method. Euphytica, v.123, p.287393, 2002. Available from: $<$ http://link.springer.com/article/10.10 23\%2FA\%3A1015065815131\#page-1>. Accessed: Jul. 28, 2014. doi: 10.1023/A:1015065815131.

DEVI, M.J. et al. Comparison of common bean (Phaseolus vulgaris L.) genotypes for nitrogen fixation tolerance to soil drying. Plant 
Soil, v.364, p.29-37, 2013. Available from: <http://link.springer. com/article/10.1007\%2Fs11104-012-1330-4\#page-1>. Accessed: Jul. 28, 2014. doi: 10.1007/s11104-012-1330-4.

FARIA, L.C. et al. Genetic progress during 22 years of improvement of carioca-type common bean in Brazil. Field Crops Research, v.142, p.68-74, 2013. Available from: <http://www.sciencedirect. com/science/article/pii/S0378429012004042>. Accessed: Jul. 28, 2014. doi: 10.1016/j.fcr.2012.11.016.

FEIJÃO: dados conjunturais do feijão (área, produção e rendimento) (Phaseolus vulgaris L.) no Brasil - 1985 to 2013. 2013. Available from: <http://www.cnpaf.embrapa.br/apps/socioeconomia/index. htm>. Accessed: Jul. 28, 2014.

FAO (FOOD AND AGRICULTURE ORGANIZATION) Faostat, 2014. Available from: <http://faostat.fao.org/site/567/ DesktopDefalt.aspx?PageID=567>. Accessed: Jul. 28, 2014.

GRANGE, L. et al. New insights into the origins and evolution of rhizobia that nodulate common bean (Phaseolus vulgaris) in Brazil. Soil Biology and Biochemistry, v.39, p.867-876, 2007. Available from: $<$ http://www.sciencedirect.com/science/article/pii/ S0038071706004615>. Accessed: Jul. 28, 2014. doi: 10.1016/j. soilbio.2006.10.008.

HUNGRIA, $M$. et al. Isolation and characterization of new efficient and competitive bean (Phaseolus vulgaris L.) rhizobia from Brazil. Soil Biology and Biochemistry, v.32, p.1515-1528, 2000a. Available from: <http://www.sciencedirect.com/science/ article/pii/S0038071700000638>. Accessed: Jul. 28, 2014. doi: 10.1016/S0038-0717(00)00063-8

HUNGRIA, M.; VARGAS, M.A.T. Environmental factors affecting N2 fixation in grain legumes in the tropics, with an emphasis on Brazil. Field Crops Research, v.65, p.151-164, 2000b. Available from: <http://www.sciencedirect.com/science/ article/pii/S0378429099000842>. Accessed: Jul. 28, 2014. doi: 10.1016/S0378-4290(99)00084-2.
OLIVEIRA, J.P. et al. Genetic diversity of rhizobia in a Brazilian oxisol nodulating Mesoamerican and Andean genotypes of common bean (Phaseolus vulgaris L.). World Journal of Microbiology and Biotechnology, v.27, p.643-650, 2011. Available from: <http:// link.springer.com/article/10.1007\%2Fs11274-010-0501-9\#page-1>. Accessed: Jul. 28, 2014. doi: 10.1007/s11274-010-0501-9.

PELEGRIN, R. et al. Resposta da cultura do feijoeiro à adubação nitrogenada e à inoculação com rizóbio. Revista Brasileira de Ciência do Solo, v.33, p.219-226, 2009. Available from: <http:// www.scielo.br/pdf/rbcs/v33n1/23.pdf>. Accessed: Jul. 28, 2014.

PEREIRA, H.S. et al. Complex interaction between genotypes and growing seasons of the carioca common bean in Goiás/Distrito Federal. Crop Breeding and Applied Biotechnology, v.10, p.207-215, 2011. Available from: <http://www.scielo.br/pdf/cbab/v11n3/a02v11n3>. Accessed: Jul. 28, 2014. doi: 10.1590/S1984-70332011000300002.

PIMENTEL-GOMES, F.P. Curso de estatística experimental. São Paulo: Nobel, 2000. 476p.

RESENDE, M.D.V.; DUARTE, J.B. Precisão e controle de qualidade em experimentos de avaliação de cultivares. Pesquisa Agropecuária Tropical, v.37, p.182-194, 2007. Available from: $<$ http://www.revistas.ufg. br/index.php/pat/article/viewFile/1867/1773>. Accessed: Jul. 28, 2014.

SILVA, N.O. et al. Performance of common bean families after different generations under natural selection. Genetics and Molecular Biology, v.27, p.574-578, 2004. Available from: <http://www.scielo. br/scielo.php?pid $=$ S1415-47572004000400018\&script $=$ sci arttext $>$. Accessed: Jul. 28, 2014. doi: 10.1590/S1415-47572004000400018.

TORGA, P.P. et al. Interaction of common beans cultivars of the black group with years, locations and sowing seasons. Euphytica, v.189, p.239-248, 2013. Available from: <http://link.springer.com/ article/10.1007\%2Fs10681-012-0793-y\#page-1>. Accessed: Jul. 28, 2014. doi: 10.1007/s10681-012-0793-y. 